\title{
Low pancreatic lipase in insulin-dependent diabetics
}

\author{
D JUNGLEE, R DE ALBARRAN, A KATRAK, DB FREEDMAN, AG BECKETT, \\ P DANDONA
}

From the Metabolic Unit, Department of Chemical Pathology, Royal Free Hospital and School of Medicine, Pond Street, London NW3 2QG

SUMMARY Serum samples obtained from 20 insulin-dependent diabetics (IDD), 23 non-insulindependent diabetics (NIDD) and 30 controls were assayed for their pancreatic lipase activity, immunoreactive trypsin concentration and glycosylated haemoglobin $\left(\mathrm{HbA}_{1}\right)$ respectively. The distribution of serum pancreatic lipase activity in normal subjects and diabetics was nonparametric. The median serum lipase activity in IDDs $(86 \mathrm{U} / \mathrm{l})$ was significantly lower that that in controls (131 U/l, p < 0.002) and NIDDs $(126 \mathrm{U} / \mathrm{l}, \mathrm{p}<0.001)$. There was a significant correlation between serum pancreatic lipase activity and serum IRT concentration $(r=0.65, p<0 \cdot 001)$. Neither pancreatic lipase activity nor IRT was related to $\mathrm{HbA}_{1}$ concentrations. These data show for the first time that serum pancreatic lipase activity is diminished in IDDs.

Diminished exocrine pancreatic reserve as reflected in reduced pancreatic trypsin ${ }^{1}$ and amylase activities ${ }^{2}$ in serum and as diminished tryptic activity in duodenal aspirates ${ }^{3}$ has been demonstrated in insulin-dependent diabetics (IDD). However, no data are available on pancreatic lipase activity in either the duodenal aspirates or the sera of diabetic patients. This study compares serum pancreatic lipase activities in controls, IDDs and non-insulindependent diabetics (NIDD), and shows for the first time that pancreatic lipase activity in IDDs is markedly lower than that in controls and NIDDs.

\section{Material and methods}

Sera from 43 patients attending the diabetic clinic were studied. They were classified on the basis of treatment: 20 IDDs and 23 NIDDs controlled with oral hypoglycaemic agents. Blood samples were collected in plain glass bottles between 10.00 and $11.30 \mathrm{~h}$ on mornings when patients attended the diabetic clinic. The samples were allowed to clot and the serum was separated by centrifugation. Separated serum was frozen at $-20^{\circ} \mathrm{C}$ until the day of the assay. Sera from 30 controls were treated similarly. The samples were thawed, shaken and assayed for pancreatic lipase activity using an enzyme kit (Boehringer). This kit is based on a turbidimetric method which uses a triolein suspension as substrate. The method also incorporates a purified colipase which renders the reaction specific for pancreatic lipase. ${ }^{4}$ The estimations were performed on the Abbott Biochromatic Analyser ABA 100 at $30^{\circ} \mathrm{C}$. Intra-assay variation was $22 \%$ at low activities and $5 \%$ at high activities.

Serum immunoreactive trypsin (IRT) was measured by a specific radioimmunoassay using a kit (Hoechst) as described before.' Glycosylated haemoglobin $\left(\mathrm{HbA}_{1}\right)$ was measured electrophoretically (Corning).

\section{Results}

The distribution of serum lipase activity amongst control subjects and diabetics was not normal, and hence non-parametric statistics (Mann Whitney $U$ test) have been used in the presentation and analysis of our data. The median serum pancreatic lipase activity in IDDs $(86 \mathrm{U} / \mathrm{l})$ was significantly lower than that in NIDDs (126 U/l, $\mathrm{p}<0.001)$ and controls (131 $U / 1, p<0.002)$. There was no significant difference between the serum pancreatic lipase activities of sulphonylurea and biguanide treated diabetics.

Serum IRT concentrations were correlated with serum pancreatic lipase activities $(r=0.65 ; p<$ 0.001 ) in the patients studied (Fig. 2).

Blood $\mathrm{HbA}_{1}$ concentrations were related to neither pancreatic lipase nor IRT.

\section{Discussion}

Our data show clearly that serum pancreatic lipase 


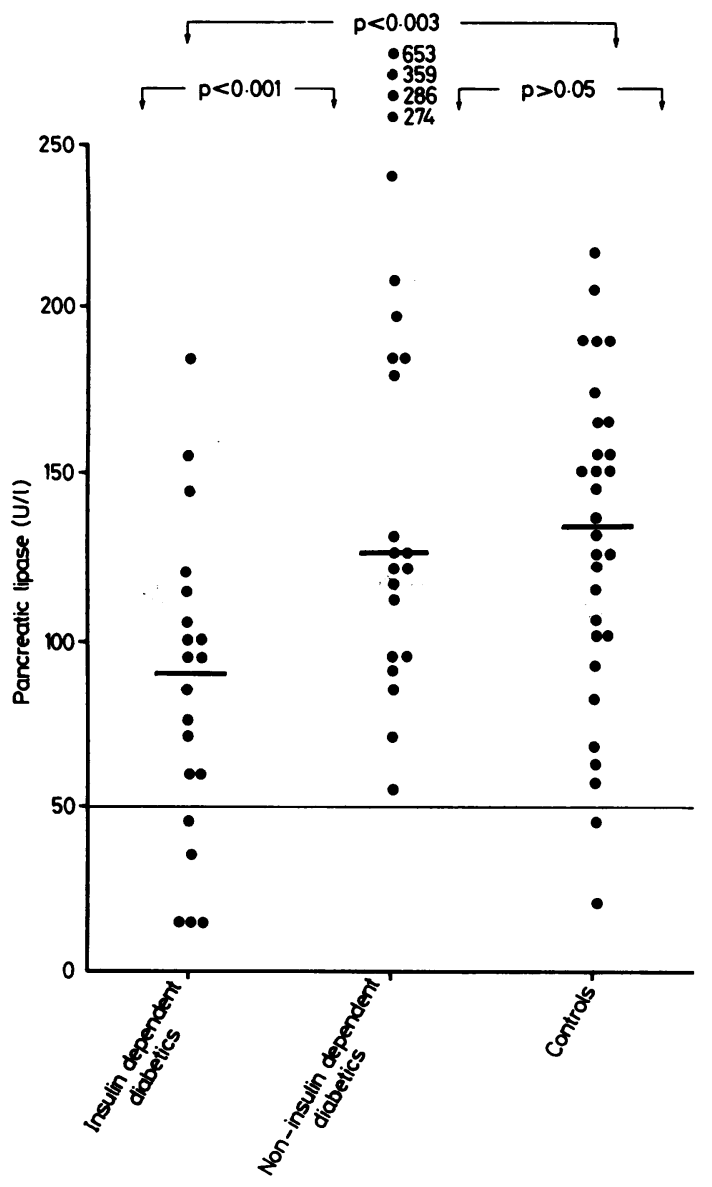

Fig. 1 Serum pancreatic lipase activities in insulindependent diabetics $(n=20)$, non-insulin-dependent diabetics $(n=23)$ and control subjects $(n=30)$.

activity in IDDs is significantly lower than that in controls, and these data parallel our previous observations with pancreatic isoamylase (PIA) and IRT. Since none of the patients investigated had steatorrhea, the diminution in pancreatic lipase was probably not of a sufficient magnitude to result in fat malabsorption. It is known that a loss of up to $80 \%$ of exocrine pancreatic reserve is necessary before fat malabsorption can occur. For example, patients with cystic fibrosis who have steatorrhoea have markedly lower IRT concentrations ${ }^{5}$ or lipase activities (unpublished observations 1982) in their sera. In contrast, patients with thalassaemia and iron overload are similar to those with IDD and have subnormal but not markedly low IRT concentrations. They do not have malabsorption. ${ }^{6}$

Our observations also show a significant correlation between pancreatic lipase activity and

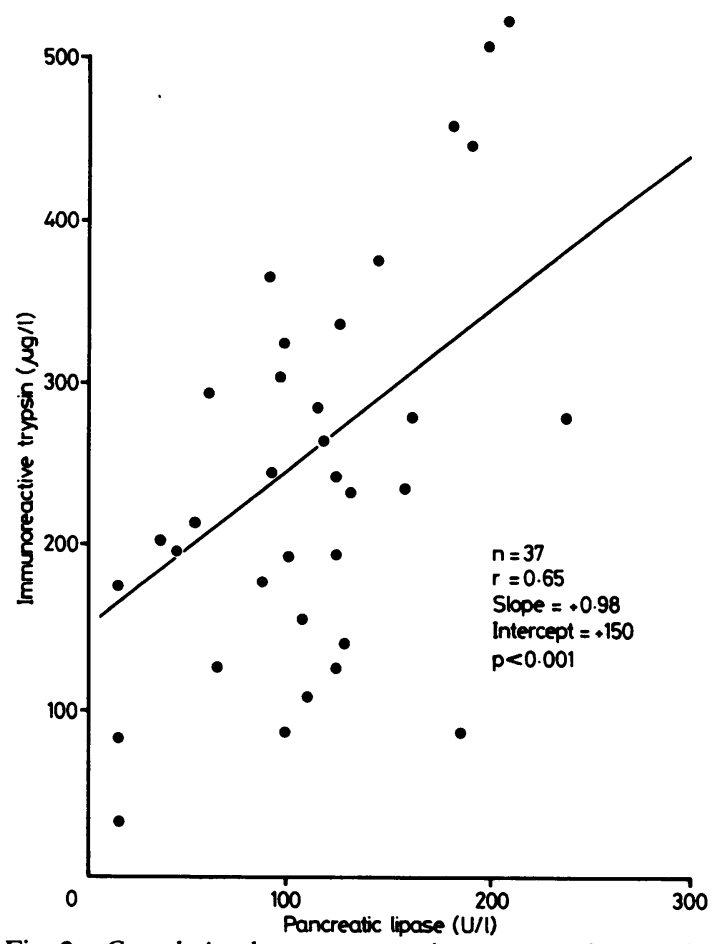

Fig. 2 Correlation between serum immunoreactive trypsin concentrations and serum pancreatic lipase activities in insulin-dependent diabetics $(n=19)$ and non-insulindependent diabetics $(n=18)$. Three non-insulin-dependent diabetics have not been included in the diagram as they were off scale but have been included in the statistical analysis (lipase: IRT values in these patients were 286:570, 653:716; 187:811).

IRT concentration. However, the correlation between pancreatic lipase and IRT was not as marked as that between IRT and PIA shown by us previously. ${ }^{2}$ We were, however, surprised to find that serum pancreatic lipase in sulphonylurea treated patients was similar to that in controls and in the biguanide-treated group. Our previous studies with IRT and PIA have shown that the activities of these enzymes in sulphonylurea-treated patients are significantly lower than those in controls and in diabetics treated with biguanides. This difference may reflect the fact that in the exocrine pancreatic injury associated with human diabetes, the sequence of enzyme loss begins with trypsin and that lipase is the last enzyme to be lost. However, this pattern is not confirmed by data obtained from experimental diabetes, where the loss of amylase and lipase activities occur prior to that of trypsin. ${ }^{7}$ We are unable to account for the markedly raised lipase activity in sera of four patients with NIDD. These patients had no evidence of acute pancreatitis but had 
concomitantly raised IRT concentrations as well. Raised IRT concentrations without associated abnormalities have previously been reported in normal subjects. The significance of such increases is not clear. ${ }^{8}$

The mechanisms underlying the diminished exocrine pancreatic function in diabetes is not yet fully elucidated; it is, however, clear that the quality of control of diabetes as reflected in $\mathrm{HbA}_{1}$ has no significant effect on either IRT or pancreatic lipase. Our recent demonstration (unpublished data 1982) that IRT is often extremely low in patients presenting with newly discovered IDD suggests that exocrine pancreatic deficit often precedes the clinical presentation of diabetes. This study includes four newly discovered IDDs, who had low serum pancreatic lipase activity and similarly low IRT concentrations. Furthermore, our preliminary studies on families of patients with IDD show abnormalities in IRT concentrations in non-diabetic relatives of diabetic patients. It would thus appear that the loss of exocrine pancreatic reserve may be related to factors which induce diabetes, rather than to diabetes itself, or to insulin therapy. As far as the clinical significance of diminished pancreatic reserve is concerned, it is possible that it may contribute to the pathogenesis of diarrhoea in patients with autonomic neuropathy, in whom a further diminution in pancreatic secretion may occur. ${ }^{9}$

The authors wish to thank Dr DP Mikhailidis, Dr
MB Gore and Mr A Leete for their help and encouragement, and Mrs P Dale and Mrs M Elleman for secretarial assistance.

\section{References}

' Dandona P, Elias E, Beckett AG. Serum trypsin levels in diabetes ڤొ mellitus. Br Med J 1978;ii:1125-6.

${ }^{2}$ Foo Y, Rosalki SB, Ramdial L, Mikhailidis DP, Dandona P. Low pancreatic isoamylase in diabetes mellitus. $J$ Clin Pathol 1980;33:1102-5.

${ }^{3}$ Frier BM, Saunders JHB, Wormsley KG, Bouchier IAD Exocrine pancreatic function in juvenile onset diabetes mellitus. Gut 1976;17:685-91.

${ }^{4}$ Hoffman GE, Weiss L. Specific serum lipase determination with use of purified colipase. Clin Chem 1980;26:1732-3.

${ }^{5}$ Dandona P, Hodson M, Bell J, Ramdial L, Beldon I, Batten JC. Serum immunoreactive trypsin in cystic fibrosis. Thorax 1981;38:60-2.

${ }^{6}$ Hussain M, Dandona P, Fedail S, Ramdial L, Flynn D, Hoffbrand AV. Serum immunoreactive trypsin in thalassaemia major. J Clin Pathol 1981;34:970-1.

${ }^{7}$ Bendayan M, Ito S. Immunocytochemistry of enzymes in normal and diabetic rat exocrine pancreas. Experientia 1978;34:933-6.

${ }^{8}$ Ruddell WS, Mitchell CJ, Hamilton I, Leek JP, Kelleher J. Clinical value of serum immunoreactive trypsin concentration. Br Med J 1981;283:1429-32.

${ }^{9}$ Mikhailidis DP, Foo Y, Ramdial L, Kirk RM, Rosalki SB, Dandona P. Pancreatic exocrine function after truncal and highly selective vagotomy. J Clin Pathol 1981;34:963-4.

Requests for reprints to: Dr P Dandona, Metabolic Unit, Department of Chemical Pathology, Royal Free Hospital, London NW3 2QG, England. 